\title{
EVALUASI PENERAPAN PSAK 102 TENTANG AKUNTANSI MURABAHAH PADA BANK BNI SYARIAH KANTOR CABANG MANDONGA
}

\author{
Oleh \\ Muntu Abdullah' ${ }^{1}$, Fitriaman ${ }^{2}$, Muh. Jabal Nur ${ }^{3}$ \\ Jurusan Akuntansi Fakultas Ekonomi dan Bisnis Universitas Halu Oleo Kendari
Sulawesi Tenggara
}

\begin{abstract}
ABSTRAK
Penelitian ini bertujuan untuk mengetahui penerapan PSAK No. 102 tentang akuntansi murabahah mengenai pengakuan, pengukuran, penyajian, dan pengungkapan pada Bank BNI Syariah Kantor Cabang Mandonga. Data yang digunakan dalam penelitan ini adalah data sekunder, teknik pengumpulan data dengan wawancara, serta analisis data dalam penelitian ini adalah deskriptif kualitatif dan kuantitatif. Hasil penelitian ini menunjukkan bahwa pelaksanaan akuntansi pembiayaan murabahah pada Bank BNI Syariah Kantor Cabang Mandonga belum sepenuhnya diterapkan sesuai dengan PSAK No. 102 tentang akuntansi murabahah. hal ini dibuktikan dengan tidak adanya pengakuan denda dan murabahah tanpa pesanan yang dijalankan Bank BNI Syariah Kantor Cabang Mandonga.
\end{abstract}

Kata Kunci : PSAK 102, Akuntansi Murabahah, BNI Syariah

\section{ABSTRACT}

This study aims to determine the application of PSAK No. 102 regarding murabahah accounting regarding recognition, measurement, presentation and disclosure at Bank BNI Syariah Mandonga Branch Office. The data used in this research are secondary data, data collection techniques by interview, and data analysis in this research is descriptive qualitative and quantitative. The results of this study indicate that the implementation of murabahah financing accounting at Bank BNI Syariah Mandonga Branch Office has not been fully implemented in accordance with PSAK No. 102 regarding murabahah accounting. this is evidenced by the absence of the recognition of fines and murabaha without orders carried out by Bank BNI Syariah Mandonga Branch Office.

Keywords : PSAK 102, Murabahah Accounting, BNI Syariah

\section{PENDAHULUAN}

Perkembangan bank syariah sampai saat ini dinilai cukup pesat, ditandai dengan berdirinya bank konvensional yang membuka cabang dengan kegiatan atau perjanjian yang sesuai hukum islam. Hal tersebut tidak lepas dari disetujuinya Undang-Undang No. 10 tahun 1998. Dalam undang-undang ini diatur dengan rinci landasan hukum serta jenis-jenis usaha yang dapat dioperasikan dan diimplementasikan oleh bank syariah. Undang-undang tersebut memberikan kesempatan bagi bank-bank konvensional untuk membuka cabang syariah atau bahkan mengkonversi diri secara total menjadi bank syariah. Terkhusus Kota Kendari yang saat ini memiliki 7 unit kantor cabang syariah yang berasal dari bank konvensional diantaranya, BNI Syariah KC Mandonga, BNI Syariah KC Kendari, Mandiri Syariah Kendari, BRI Syariah Kendari, Mega Syariah Kendari, BTPN Syariah Kendari, serta BTN Syariah Kendari.

Kegiatan operasional bank syariah salah satunya adalah mendistribusikan pembiayaan. Menurut Undang-undang perbankan No. 10 tahun 1998, Pembiayaan adalah penyediaan uang atau tagihan yang dapat dipersamakan dengan itu, berdasarkan persetujuan atau kesepakatan antara bank dan pihak lain yang dibiayai untuk 
mengembalikan uang atau tagihan tersebut setelah jangka waktu tertentu dengan imbalan atau bagi hasil.

Pembiayaan merupakan kegiatan operasional bank yang memang sangat besar dan banyak serta dari pembiayaan bank syariah banyak mendapatkan pendapatan. Pendapatan bank syariah akan baik apabila pengembalian dana dari pembiayaan tersebut terjadi dengan lancar atau tidak banyak hambatan, dengan kata lain nasabah dapat mengembalikan dana pinjamannya, yang tentunya akan menghasilkan laba bagi perusahaan. Bank syariah biasanya memiliki berbagai macam jenis pembiayaan yang salah satunya adalah pembiayaan murabahah. Murabahah merupakan produk finansial yang berbasis $b a{ }^{\prime} i$ atau jual beli. Murabahah adalah produk pembiayaan yang paling banyak digunakan oleh perbankan syariah didalam kegiatan usaha. pada dewasa ini murabahah menduduki porsi 66\% dari semua transaksi investasi bank-bank syariah (Islamic Banks) di dunia.(Ashraf Usmani, t.th.: 45).

Wiroso (2011:168) Transaksi yang paling banyak dilakukan oleh bank syariah saat ini adalah murabahah, bahkan BPR Syariah hampir seluruh transaksinya adalah murabahah. Salah satu alasannya adalah dalam murabahah ini risiko bagi bank syariah adalah kecil, bahkan kadang-kadang disamakan kredit investasi. Sedangkan pada Bank BNI Syariah Kantor Cabang Mandonga berdasarkan informasi yang diberikan dari staff pembiayaan saat pra penelitian, bahwasannya aktivitas pembiayaan yang diberikan BNI Syariah Kantor Cabang Mandonga tahun 2016 sampai 2018 hanya pembiayaan murabahah hal ini terjadi karena segmen usaha yang dijalankan terbatas pada segmen mikro saja dan kebutuhan nasabah yang mengajukan pembiayaan pada rentang tahun tersebut memang sesuai kebutuhan untuk pembiayaan murabahah. Kemudian memasuki tahun 2019 Bank BNI Syariah KC Mandonga melakukan ekspansi pembiayaan sesuai dengan kebutuhan masyarakat dengan memberikan pembiayaan musyarakah, ijarah, dan hawalah bil ujrah.

Bank syariah dalam seluruh transaksinya pencatatan yang dilakukan harus sesuai dengan standar akuntansi yang berlaku. Standar akuntansi keuangan digunakan sebagai acuan atau pedoman dalam pembuatan laporan keuangan, dalam kaitannya dengan proses pengakuan, pengukuran, penyajian, dan pengungkapan (Pratiwi dan Septiarini, 2014). Lembaga keuangan syariah, seharusnya sudah mengacu pada PSAK No. 102 dalam menjalankan kegiatan pembiayaan, khususnya pembiayaan murabahah. Berdasarkan Pernyataan Dewan Standar Akuntansi Keuangan Indonesia (DSAK IAI) pada 27 Juni 2007 yang telah diahlikan kewenangannya pada Dewan Standar Akuntansi Syariah (DSAS IAI), PSAK 102 diterapkan untuk lembaga keuangan syariah dan koperasi syariah yang melakukan transaksi murabahah baik sebagai penjual maupun pembeli dengan lembaga keuangan syariah atau koperasi syariah. Akan tetapi, fakta yang ada menunjukkan belum semua lembaga keuangan syariah menerapkan apa yang sudah ditentukan dalam PSAK No. 102 tentang akuntansi murabahah.

Fenomena tersebut dibuktikan dari penelitian yang dilakukan Rusydi dan Nasir (2009), yang menunjukkan bahwa dalam mengimplementasikan PSAK No. 102 dalam hal pengakuan dan pengukuran. PT. Bank Syariah Mandiri Cabang Makassar belum sepenuhnya menerapkan PSAK No. 102 tentang akuntansi murabahah. Hal ini ditandai dengan surat edaran operasional yang dikeluarkan hanya mengatur bank sebagai penjual saja, sedangkan dalam PSAK No. 102 tidak hanya mengatur ketentuan dari perspektif penjual saja melainkan juga perspektif dari pembeli. Penelitian Inggrid Eka Pratiwi (2014), Menunjukkan bahwa KSU BMT Rahmat Syariah Kediri dalam hal pengakuan, pengukuran, penyajian dan pengungkapan tidak sesuai dengan penerapan PSAK No. 102.

Penelitian oleh Haryanto (2015), menunjukkan bahwa BMT Ummah Banjarmasin perlakuan akuntansi PSAK No. 102 tentang akuntansi murabahah belum sepenuhnya 
memenuhi. Hal ini dapat dibuktikan beberapa yang masih perlu dilakukan perbaikan seperti belum adanya perlakuan akuntansi urbun murabahah, perlakuan akuntansi potongan dini, dan tidak adanya denda pada saat nasabah tidak bisa membayar cicilan.

Rumusan masalah dalam penelitian ini adalah Bagaimana Pengakuan, pengukuran, penyajian, dan pengungkapan PSAK 102 tentang transaksi akuntansi murabahah pada Bank BNI Syariah Kantor Cabang Mandonga, sedangkan tujuan dari penelitian ini adalah untuk mengetahui penerapan PSAK 102 transaksi pembiayaan murabahah pada Bank BNI Syariah Kantor Cabang Mandonga.

\section{TINJAUAN PUSTAKA}

Akuntansi syariah merupakan akuntansi yang mempunyai 3 komponen prinsip diantaranya prinsip pertanggungjawaban (accountability), prinsip keadilan, dan prinsip kebenaran yang berdasarkan pada hukum syariah dan bersifat universal. Konsep yang mendasari penyusunan dan penyajian laporan keuangan syariah bagi pengguna yaitu penyusunan standar akuntansi keuangan syariah dalam pelaksanaan tugasnya, penyusunan laporan keuangan, untuk menanggulangi masalah yang belum diatur dalam standar akuntansi keuangan akuntansi syariah, auditor dalam memberikan pendapat mengenai apakah laporan keuangan disusun sesuai dengan prinsip akuntansi syariah yang berlaku umum, para pemakai laporan keuangan, dalam menafsirkan informasi yang disajiikan dalam laporan keuangan yang disusun sesuai dengan standar akuntansi keuangan syariah (Muhammad, 2005).

Dalam Undang-undang No. 21 tahun 2008 pasal 1 ayat 7 dijelaskan bahwa bank syariah adalah bank yang menjalankan kegiatan usahanya berdasarkan prinsip syariah dan menurut jenisnya terdiri atas bank umum syariah dan bank pembiayaan rakyat syariah. Menurut Muhammad (2005;13) bank syariah adalah lembaga keuangan yang usaha pokoknya memberikan pembiayaan dan jasa-jasa lainnya dalam lalu lintas pembayaran serta peredaran uang yang pengoperasiannya disesuaikan dengan prinsip syariat islam. Dalam kegiatan operasionalnya bank syariah menjalankan beberapa fungsi dan peranan, menurut Syafi'i Antonio (2010) bahwa dalam paradigma islam bank syariah memiliki fungsi sebagai berikut: manajemen investasi, investasi, jasa-jasa keuangan dan jasa sosial.

Secara garis besar pengembangan produk bank syariah dikelompokkan menjadi tiga kelompok, yaitu produk penghimpunan dana, produk penyaluran dana, dan produk jasa. Ketiga kelompok bank syariah tersebut menurut Muhammad dan Suwiknyo (2009;13) adalah sebagai berikut: (1) Produk penghimpunan dana yang terdiri dari prinsip Wadi'ah dan prinsip Mudharabah, (2) Produk penyaluran dana yang terdiri dari prinsip jual beli, prinsip Ijarah dan prinsip Syirkah, (3) Produk jasa yang dikembangkan dengan akad alhiwalah, ar-rahn, al-qardh, al-wakalah, dan al-kafalah.

Pembiayaan dipakai untuk mendefinisikan pendanaan yang dilakukan oleh lembaga pembiayaan seperti bank syariah kepada nasabah, pembiayaan secara luas berarti financing atau pembelanjaan yaitu pendanaan yang dikeluarkan untuk mendukung investasi yang telah direncanakan, baik dikerjakan sendiri maupun dikerjakan oleh orang lain. (Rusby, 2015:9). Istilah pembiayaaan pada intinya merupakan lembaga pembiayaan yang selaku shahibul mal menaruh kepercayaan kepada seseorang untuk melaksanakan amanah yang diberikan. Dana dikelola dengan benar, adil, dan harus disertai ikatan dan syarat-syarat yang jelas, dan saling menguntungkan bagi pihak.

Pembiayaan pada dasarnya diberikan atas dasar kepercayaan dengan memuat unsurunsur berikut: adanya dua pihak, adanya kepercayaan shahibul mal dan mudharib didasarkan atas prestasi dan potensi mudharib, adanya persetujuan, adanya penyerahan barang, jasa, atau uang dari shahibul mal kepada mudharib, adanya unsur waktu, adanya 
unsur resiko baik dipihak shahibul mal maupun pihak mudharib. Tujuan pembiayaan dibedakan menjadi dua kelompok yaitu tujuan pembiayaan untuk tingkat makro adalah untuk meningkatkan ekonomi masyarakat, tersedianya dana bagi peningkatan usaha, peningkatan produktivitas, membuka lapangan kerja baru, terjadinya distribusi pendapatan.dan tujuan pembiayaan untuk tingkat mikro adalah untuk memaksimalkan laba, meminimkan resiko, pendayagunaan sumber ekonomi, dan penyaluran kelebihan dana.

Mardani (2015: 136) menjelaskan bahwa murabahah biasa disebut bai'bitsamanil 'ajil, asal katanya adalah ar-ribhu yang artinya adalah keuntungan, sehingga murabahah diartikan dengan saling menguntungkan. Secara terminologi, murabahah adalah akad pembiayaan yang saling menguntungkan yang dilakukan pemilik harta dengan pihak yang membutuhkan, melalui transaksi jual beli dengan cara meyebutkan harga perolehan barang, dan dalam harga jual terdapat nilai lebih yang dihitung sebagai keuntungan bagi pemilik harta, serta pembayarannya dapat dilakukan dengan cara tunai maupun kredit.

PSAK No. 102 Murabahah didefinisikan sebagai "akad jual beli barang dengan harga jual sebesar biaya perolehan ditambah keuntungan yang disepakati dan penjual harus mengungkapkan biaya perolehan barang tersebut kepada pembeli” (IAI, 2019: 102). Akad Murabahah terbagi menjadi dua jenis, yaitu murabahah dengan pesanan dan murabahah tanpa pesanan (Nurhayati, 2015: 177-178).

PSAK No.102 Revisi 2019 tentang akuntansi murabahah merupakan sistem akuntansi yang melihat bagaimana proses pencatatan terhadap produk pembiayaan yang memakai sistem jual beli dari pihak-pihak yang terkait menjadi sistem akuntansi yang dapat diterapkan untuk lembaga keuangan syariah seperti bank, asuransi, lembaga pembiayaan dana pensiun, koperasi dan yang lainnya yang menjalankan transaksi murabahah.

\section{METODE PENELITIAN}

Penelitian ini dilakukan pada Bank BNI Syariah Kantor Cabang Mandonga yang berlokasi di Jl. Syech Yusuf, No. 12, Kel. Korumba, Kec. Mandonga Kendari, Sulawesi Tenggara. Objek dalam penelitian ini adalah evaluasi penerapan PSAK 102 tentang akuntansi murabahah. Jenis data yang digunakan dalam penelitian ini yaitu data kualitatif dan data kuantitatif, sedangkan sumber data dari penelitian ini berasal dari dua sumber antara lain data primer dan data sekunder. Metode pengumpulan data yang digunakan yaitu wawancara dan dokumentasi. Analisis yang digunakan dalam penelitian ini adalah analisis deskriptif. Analisis deskriptif yaitu suatu metode analisis dengan terlebih dahulu mengumpulkan data, mengklasifikasikan serta menginterprestasikan data sehingga dapat memberikan gambaran yang jelas mengenai masalah yang diteliti. Teknik analisis deskriptif dimaksudkan untuk menguraikan atau memaparkan hasil penelitian untuk kemudian dilakukan interprestasi berdasarkan landasan teori yang telah disusun. Metode yang digunakan untuk menganalisis data penelitian ini adalah analisis deskriptif yaitu mendeskripsikan penerapan standar PSAK 102 tentang akuntansi murabahah yang diterapkan Bank BNI Syariah Kantor Cabang Mandonga.

\section{HASIL DAN PEMBAHASAN}

\section{Hasil Penelitian}

Evaluasi Penerapan PSAK No.102 Tentang Pengakuan dan Pengukuran Akuntansi Pembiayaan Murabahah Pada Bank BNI Syariah Kantor Cabang Mandonga

\section{Aset Murabahah}

Dalam ketentuan PSAK 102 revisi 2019, disebutkan bahwa asset murabahah diukur sebagai persediaan sebesar biaya perolehan. Pada praktiknya Bank BNI Syariah Kantor 
Cabang Mandonga mengakui aset yang diperoleh sebagai persediaan dimana pihak Bank terlebih dahulu harus menguasi ataupun memiliki objek dari transaksi murabahah sebelum berlangsungnya transaksi jual beli.

\section{Diskon Pembelian Persediaan Murabahah}

Dalam PSAK No. 102 revisi 2019, terkait diskon pembelian persediaan murabahah yang terjadi setelah akad diakui sebagai:

a. Liabilitas kepada pembeli, jika diskon tersebut merupakan hak pembeli sesuai yang diperjanjikan dalam akad murabahah atau jika tidak diperjanjikan dalam akad murabahah.

b. Penghasilan periode berjalan, jika diskon tersebut merupakan hak penjual sesuai yang diperjanjikan dalam akad.

Dalam praktiknya, Bank BNI Syariah Kantor Cabang Mandonga mengakui adanya diskon pembelian aset. Jika diskon diberikan setelah terjadinya akad dan memenuhi prasyarat yang dijanjikan milik nasabah maka bank akan memberikan kewajiban diskon kepada nasabah, jika dalam akad yang diperjanjikan merupakan hak milik Bank maka akan diakui sebagai penghasilan/keuntungan.

\section{Piutang Murabahah}

Dalam PSAK No. 102 revisi 2019 dijelaskan bahwa pada saat akad murabahah, piutang murabahah diakui sebesar jumlah tagihan kepada pembeli. Dalam praktik BNI Syariah Kantor Cabang Mandonga mengakui piutang murabahah pada saat terjadinya akad, sebesar biaya yang diperoleh dari aset murabahah kemudian ditambah keuntungan yang sudah disepakati oleh bersama. pencatatannya dilakukan setiap bulan ketika nasabah hendak melakukan pembayaran cicilan.

\section{Uang Muka Murabahah}

Dalam PSAK No. 102 revisi 2019, uang muka dari pembeli dapat diakui sebagai :

a. Pengurang biaya perolehan persediaan murabahah

b. Pengurang tagihan kepada pembeli.

Bank BNI Syariah Kantor Cabang Mandonga dalam praktiknya, menetapkan uang muka kepada nasabah untuk diserahkan kepada pihak bank. Besaran uang muka yang diterima tergantung dengan kemampuan nasabah itu sendiri. Dana uang muka yang diterima nantinya akan diakui sebagai pembayaran piutang murabahah.

\section{Pendapatan Murabahah}

Dalam PSAK No. 102 revisi 2019 pendapatan murabahah diakui:

a. Pada saat penjual mengalihkan pengendalian atas persediaan kepada pembeli jika murabahah dilakukan secara tunai atau tangguh yang tidak mengandung unsur signifikan.

b. b. Selama periode akad secara proporsional jika murabahah dilakukan mengandung unsur pembiayaan signifikan dan penjual memiliki risiko signifikan terkait kepemilikan persediaan.

Dalam praktik yang terjadi pada Bank BNI Syariah kantor Cabang Mandonga mengakui pendapatan selama periode akad. Pendapatan diakui sebesar jumlah yang dapat ditagih dari piutang murabahah, dalam hal ini ketika nasabah melakukan cicilan pelunasan setiap bulannya.

\section{Potongan Pelunasan Piutang}

Dalam PSAK No. 102 revisi 2019, Potongan pelunasan piutang murabahah diakui sebagai pengurang pendapatan murabahah periode berjalan. Dalam Praktik Bank BNI Syariah Kantor Cabang Mandonga mengakui adanya potongan pelunasan piutang murabahah, namun dalam akad tidak diperjanjikan pemberian potongan pelunasan 
piutang. potongan ini diberikan tergantung dari keputusan Pimpinan Bank terhadap nasabah. potongan pelunasan piutang ini diakui sebagai pengurang pendapatan murabahah yang harusnya didapat oleh bank dan diberikan pada saat setelah pelunasan.

\section{Potongan Piutang Murabahah}

Dalam PSAK No. 102 revisi 2019, Potongan atas piutang murabahah yang belum dilunasi mengubah besaran pendapatan murabahah. Dalam praktik yang terjadi pada Bank BNI Syariah Kantor Cabang Mandonga tidak memberikan potongan piutang murabahah yang belum dilunasi kepada nasabah, pihak Bank hanya memberikan bagi nasabah fasilitas R3 (Rescheuduling, Restrutucturing, Reconditioning) berupa peninjauan ulang terhadap kondisi nasabah.

\section{Denda}

Dalam PSAK No. 102 revisi 2019, Denda yang diterima dari pembeli diakui sebagai liabilitas. Praktik yang terjadi pada Bank BNI Syariah Kantor Cabang Mandonga tidak menerapkan denda kepada nasabah yang melakukan penunggakan terhadap kewajibannya, pihak bank hanya memberikan surat peringatan terhadap nasabah dan tidak ada penambahan jumlah dari nominal dari kelalaian tersebut jadi kewajibannya tetap seperti pada saat akad.

Evaluasi Penerapan PSAK No. 102 Tentang Penyajian Akuntansi Pembiayaan Murabahah Pada Bank BNI Syariah Kantor Cabang Mandonga

\section{Penyajian Piutang Murabahah}

Dalam PSAK No. 102 revisi 2019, disebutkan Piutang murabahah disajikan sebesar nilai bersih yang dapat direalisasikan, yaitu saldo piutang murabahah dikurangi penyisihan kerugian piutang. Dalam praktik yang terjadi pada BNI Syariah Kantor Cabang Mandonga piutang murabahah disajikan sebesar biaya yang dapat direalisasikan. perhitungannya saldo piutang dikurang dengan penyisihan kerugian piutang yang dibuat bank.

\section{Penyajian Pendapatan Murabahah}

PSAK No. 102 revisi 2019, disebutkan Pendapatan murabahah tangguhan dan biaya transaksi disajikan sebagai pengurang (contra account) piutang murabahah. Dalam praktik BNI Syariah Kantor Cabang Mandonga menyajikan murabahah tangguhan sebagai pengurang dari piutang murabahah dalam akun pendapatan margin murabahah yang ditangguhkan.

\section{Penyajian Beban Murabahah}

PSAK No.102 revisi 2019 disebutkan, Beban murabahah tangguhan disajikan sebagai pengurang (contra account) Utang murabahah. Dalam praktik BNI Syariah Kantor Cabang Mandonga menyajikan beban murabahah tangguhan sebagai pengurang utang murabahah.

Evaluasi Penerapan PSAK No. 102 Tentang Pengungkapan Akuntansi Pembiayaan Murabahah Pada Bank BNI Syariah Kantor Cabang Mandonga

Dalam PSAK No. 102 revisi 2019, Penjual mengungkapkan hal-hal yang terkait dengan transaksi murabahah, tetapi tidak terbatas pada :

1. Harga perolehan aset murabahah;

2. Janji pemesanan dalam murabahah berdasarkan pesanan sebagai kewajiban atau bukan; dan

3. Pengungkapan yang diperlukan sesuai PSAK 101: Penyajian Laporan Keuangan Syariah.

Dalam praktik BNI Syariah Kantor Cabang Mandonga penyusunan laporan keuangan dilakukan terpusat, artinya kantor pusat yang menyusun laporan keuangan berdasarkan data yang diperoleh dari kantor cabang dan laporan yang disajikan sudah sesuai 
Jurnal Akuntansi dan Keuangan (JAK)

Volume 6, No. 1 Februari Tahun 2021

Page: $67-77$

http://ojs.uho.ac.id/index.php/iak-uho/issue/archive

e-ISSN: 2088-4656

dengan PSAK 101 tentang penyajian laporan keuangan syariah, namun untuk harga perolehan aset tidak diungkapkan secara terperinci.

\section{Pembahasan}

Penerapan PSAK No. 102 Tentang Pengakuan dan Pengukuran Akuntansi Pembiayaan Murabahah Pada Bank BNI Syariah Kantor Cabang Mandonga

Pengakuan menurut Kerangka Dasar Penyusunan dan Penyajian Laporan Keuangan Syariah (KDPPLKS) paragraf 109 merupakan proses pembentukan suatu pos yang memenuhi suatu definisi unsur serta kriteria pengakuan yang dikemukakan dalam paragraf 110 dalam neraca atau laporan laba rugi. Pengukuran menurut Kerangka Dasar Penyusunan dan Penyajian Laporan Keuangan Syariah (KDPPLKS) paragraf 127 merupakan proses penetapan jumlah uang untuk mengakui dan memasukkan setiap unsur laporan keuangan dalam neraca dan laporan laba rugi.

Dalam PSAK No. 102 revisi 2019 tentang akuntansi pembiayaan murabahah menjelaskan bahwa pada saat perolehan aset murabahah diukur pada biaya perolehan. Bank BNI Syariah Kantor Cabang Mandonga mengakui aset sebagai persediaan dimana pada saat akad murabahah objek yang diperjualbelikan terlebih dahulu dikuasai oleh bank dan diakui sebagai persediaaan sebelum diberikan kepada nasabah meskipun dalam pembeliannya menggunakan sistem wakalah (pemberian Kuasa Pembelian pada nasabah). metode yang digunakan BNI Syariah Kantor Cabang Mandonga pembelian secara langsung dan sistem wakalah dalam artian pemberian kuasa pembelian terhadap nasabah namun hanya dalam pengurusan saja tetapi untuk pembelian tetap menjadi milik bank. Ilustrasi pencatatan jurnal pengakuan persediaan :

Tanggal 1 April 2019 atas pesanan pembelian barang dari Tuan Amir, Bank BNI Syariah Kantor Cabang Mandonga membeli sebuah Mobil dari PT. A seharga Rp. 100.000.000,00 atas pembelian mobil tersebut. jurnal yang dilakukan adalah sebagai berikut :

Aset/ persediaan murabahah

Kas/ Rekening PT. A

Rp. 100.000.000,00

Rp. $100.000 .000,00$

Jika menggunakan Sistem wakalah Bank BNI Syariah Kantor Cabang Mandonga memberi kuasa kepada Tuan Amir untuk membeli mobil dan menyerahkan uang tunai sebesar Rp. 100.000.000,00 atas transaksi tersebut jurnal sebagai berikut :

Piutang Wakalah

Rekening Tuan Amir

Rp. 100.000.000,00

Rp. $100.000 .000,00$

Dalam pengakuan Diskon BNI Syariah Kantor Cabang Mandonga ketika penjual/pemasok memberikan potongan harga pada pembeli setelah terjadinya akad antara bank dan nasabah, maka diskon ini diakui bank sebagai liabilitas yang harus diserahkan kepada nasabah dan menjadi pendapatan bank jika yang diperjanjikan dalam akad milik bank. Ilustrasi pengakuan diskon:

Pada tanggal 15 Mei 2019 BNI Syariah Kantor Cabang Mandonga menerima potongan harga atas pembelian mobil dari PT. A setelah terjadinya akad jual beli dengan Tuan Amir, Potongan harga yang diterima sebesar Rp.3.000.000,00 atas transaksi tersebut dapat dijurnal :

Jurnal jika menjadi Hak milik nasabah :

Kas

Hutang Diskon Murabahah

Rp. $3.000 .000,00$

Jurnal jika menjadi Hak milik Bank :

Kas

Pendapatan Murabahah

Rp. $3.000 .000,00$

Jurnal Akuntansi dan Keuangan Fakultas Ekonomi dan Bisnis, UHO

Rp. $3.000 .000,00$

$$
\text { Rp. } 3.000 .000,00
$$


Bank BNI Syariah Kantor Cabang Mandonga mengakui adanya piutang murabahah pada saat terjadinya akad dan diakui sebesar biaya yang diperoleh dari nasabah ditambah keuntungan atau margin yang telah disepakati. Ilustrasi pengakuan piutang:

Pada tanggal 15 juni 2019 disepakati transaksi jual beli antara Bank BNI Syariah Kantor Cabang Mandonga dengan Tuan Amir, dengan harga jual sebesar Rp.120.000.000,00 dengan keuntungan yang disepakati sebesar Rp.20.000.000,00 sesuai dengan catatan yang ada pada bank BNI Syariah Kantor Cabang Mandonga nilai persediaan (harga perolehan) mobil yang dipesan oleh Tuan Amir sebesar Rp.100.000.000,00 pembayaran jual beli tersebut dilakukan dengan cara tangguh selama jangka waktu 10 bulan dan dilakukan setiap tanggal 15 sebesar Rp.12.000.000,00 (dalam administrasi bank syariah setiap angsuran dilakukan pembagian untuk angsuran pokok sebesar Rp.10.000.000,00 dan untuk pembayaran margin sebesar Rp.2.000.000,00) Atas transaksi tersebut jurnal :

Piutang Murabahah

Rp. 120.000.000,00

Persediaan/aset murabahah

Margin Murabahah tangguhan

Jurnal Pembayaran angsuran pertama :

Kas/Rekening Tuan Amir

Piutang murabahah
Rp. $100.000 .000,00$

Rp. 20.000.000,00

Praktik BNI Syariah Kantor Cabang Mandonga untuk Pendapatan murabahah diakui selama periode akad dengan menggunakan metode besaran jumlah yang dapat ditagih dari nasabah pada setiap setorannya (Metode Proporsional). Berikut ini contoh perhitungan pendapatan secara proporsional untuk suatu transaksi murabahah antara Bank BNI Syariah Kantor Cabang Mandonga dengan Tuan Amir, Biaya perolehan aset (pokok) Rp.100.000.000,00 dan keuntungan yang disepakati dalam akad Rp.20.000.000,00 dengan harga jual Rp.120.000.000,00 serta pembayaran dilakukan secara angsuran selama 10 Bulan dengan angsuran perbulan Rp. 12.000.000,00. Jadi Jumlah angsuran, pokok dan keuntungan yang diakui setiap bulan adalah sebagai berikut :

\section{Tabel 4.1}

Metode Perhitungan Proporsional

\begin{tabular}{|l|l|l|l|}
\hline Bulan & Angsuran & Pokok & Keuntungan \\
\hline 1 & Rp. $12.000 .000,00$ & Rp. $10.000 .000,00$ & Rp. $2.000 .000,00$ \\
\hline 2 & Rp. $12.000 .000,00$ & Rp. $10.000 .000,00$ & Rp. $2.000 .000,00$ \\
\hline 3 & Rp. $12.000 .000,00$ & Rp. $10.000 .000,00$ & Rp. $2.000 .000,00$ \\
\hline 4 & Rp. $12.000 .000,00$ & Rp. $10.000 .000,00$ & Rp. $2.000 .000,00$ \\
\hline 5 & Rp. $12.000 .000,00$ & Rp. $10.000 .000,00$ & Rp. $2.000 .000,00$ \\
\hline 6 & Rp. $12.000 .000,00$ & Rp. $10.000 .000,00$ & Rp. $2.000 .000,00$ \\
\hline 7 & Rp. $12.000 .000,00$ & Rp. $10.000 .000,00$ & Rp. $2.000 .000,00$ \\
\hline 8 & Rp. $12.000 .000,00$ & Rp. $10.000 .000,00$ & Rp. $2.000 .000,00$ \\
\hline 9 & Rp. $12.000 .000,00$ & Rp. $10.000 .000,00$ & Rp. $2.000 .000,00$ \\
\hline 10 & Rp. $12.000 .000,00$ & Rp. $10.000 .000,00$ & Rp. $2.000 .000,00$ \\
\hline Total & Rp.120.000.000,00 & Rp.100.000.000,00 & Rp.20.000.000,00 \\
\hline
\end{tabular}

Bank BNI Syariah Kantor Cabang Mandonga mengakui uang muka sebesar jumlah nominal yang diterima dari nasabah pada saat akad dan jika nasabah jadi membeli, maka uang muka diakui sebagai pembayaran piutang. apabila dalam perjalanannya nasabah batal membeli 
Jurnal Akuntansi dan Keuangan (JAK)

Volume 6, No. 1 Februari Tahun 2021

Page: $67-77$

http://ojs.uho.ac.id/index.php/jak-uho/issue/archive

e-ISSN: 2088-4656

maka pihak bank melakukan pengembalian dengan memperhatikan biaya-biaya yang dikeluarkan pihak bank. Ilustrasi pencatatan jurnal :

Pada tanggal 5 Juni 2019 sebagai tanda keseriusan pemesanan pembelian mobil kepada Bank BNI Syariah Kantor Cabang Mandonga, Tuan Amir menyerahkan uang muka sebesar Rp. 10.000.000,00 sesuai kesepakatan kedua belah pihak. Jurnal :

Kas/Rekening Tuan Amir

Hutang Uang Muka

Rp. 10.000.000,00

Rp. $10.000 .000,00$

BNI Syariah Kantor Cabang Mandonga tidak memberikan perjanjian dalam akad mengenai potongan pembayaran piutang bagi nasabah yang melakukan pembayaran secara tepat waktu, tetapi dalam perjalanannya bank bisa melakukukan potongan pembayaran hal ini tergantung kebijakan dari pimpinan dan negosiasi antara nasabah dan bank, pemberian potongan hanya diberikan pada saat setelah pelunasan. Bank BNI Syariah kantor Cabang mandonga dalam transaksi murabahah tidak memberikan potongan piutang murabahah yang belum dilunasi kepada nasabah, pihak bank hanya memberikan fasilitas R3 (Rescheuduling, Restrutucturing, Reconditioning) sebagai upaya agar pembiayaan tersebut dapat berjalan.

Untuk pembiayaan macet, Bank BNI Syariah Kantor Cabang Mandonga tidak menetapkan denda pada nasabah yang lalai dalam melakukan pembayaran tepat waktu walaupun dalam PSAK No.102 mengatur hal tersebut, nasabah yang lalai hanya diberi surat peringatan dan jumlah kewajiban yang dikenakan masih sama dengan nominal awalnya tanpa adanya penambahan dari pihak bank, hal ini terjadi karena menurut pihak Bank BNI Syariah Kantor Cabang Mandonga denda bersifat memberatkan pihak lain dalam artian nasabah dan mengurangi nilai prinsip syariah dalam praktik Bank islam.

Penerapan PSAK No. 102 Tentang Penyajian Akuntansi Pembiayaan Murabahah Pada Bank BNI Syariah Kantor Cabang Mandonga

Dalam PSAK No. 102 revisi 2019 dijelaskan bahwa :

1. Piutang murabahah disajikan sebesar nilai bersih yang dapat direalisasikan, yaitu saldo piutang murabahah dikurangi penyisihan kerugian piutang.

2. Margin murabahah tangguhan disajikan sebagai pengurang (contra account) piutang murabahah.

3. Beban murabahah tangguhan disajikan sebagai pengurang (contra account) hutang murabahah.

Berdasarkan informasi yang diperoleh dari pihak Bank BNI Syariah Kantor Cabang Mandonga dalam penyajian laporan keuangan yang dipublikasikan oleh kantor pusat BNI Syariah, piutang murabahah disajikan sebesar jumlah yang dapat direalisasi, dan margin dari murabahah tangguhan disajikan sebagai pengurang piutang murabahah sedangkan untuk beban murabahah disajikan sebagai pengurang hutang murabahah.

Praktik Penyajian laporan BNI Syariah Kantor Cabang Mandonga Kendari sudah sesuai dengan penyusunan laporan PSAK 101 namun untuk dokumentasi data laporan posisi keuangan pimpinan Bank BNI Syariah Kantor Cabang Mandonga tidak memberikan izin untuk perolehan data dalam penelitian ini dikarenakan merupakan privasi dari Bank tersebut.

Penerapan PSAK No. 102 Tentang Pengungkapan Akuntansi Pembiayaan Murabahah dengan Bank BNI Syariah Kantor Cabang Mandonga

Pengungkapan adalah suatu informasi yang disertakan sebagai lampiran pada laporan keuangan untuk catatan kaki atau tambahan (Yahdiyani,2015). Dalam PSAK No. 102 revisi 
Jurnal Akuntansi dan Keuangan (JAK)

Volume 6, No. 1 Februari Tahun 2021

Page: $67-77$

http://ojs.uho.ac.id/index.php/iak-uho/issue/archive

e-ISSN: 2088-4656

2019 dijelaskan bahwa penjual mengungkapkan hal-hal yang terkait dengan transasksi murabahah tetapi tidak terbatas pada :

1. Harga perolehan aset murabahah.

2. Janji pemesanan dalam murabahah berdasarkan pesanan sebagai kewajiban.

3. Pengungkapan yang diperlukan sesuai PSAK 101: Penyajian Laporan Keuangan Syariah.

Dalam Penyusunan laporan keuangan BNI Syariah Kantor Cabang Mandonga menggunakan sistem yang terpusat artinya, Kantor Pusat yang melakukan penyusunan laporan keuangan sementara Kantor Cabang hanya menarikkan data lalu kemudian memberikan pada Kantor Pusat. dalam hal ini laporan yang disusun sesuai PSAK 101, dapat dilihat dihalaman lampiran yang mengungkapkan laporan posisi keuangan, laporan laba rugi dan penghasilan komprehensif lainnya, laporan perubahan ekuitas, laporan arus kas, dan catatan atas laporan keuangan, namun untuk harga perolehan aset murabahah tidak diungkapkan secara rinci. Adapun opini auditor terhadap laporan keuangan Bank BNI Syariah Kantor Cabang Mandonga berdasarkan informasi yang diberikan Staff Financing Administration Head diungkapkan dengan Opini wajar tanpa pengecualian, namun untuk dokumentasi dari pengungkapan laporan keuangan bank BNI Syariah Kantor Cabang Mandonga tidak dapat dipublikasikan dikarenakan privasi dari Bank tersebut.

\section{KESIMPULAN DAN SARAN}

\section{Kesimpulan}

Hasil penelitian dan pembahasan Evaluasi Penerapan PSAK 102 Tentang Akuntansi Murabahah Pada Bank BNI Syariah Kantor Cabang Mandonga, maka peneliti dapat menarik kesimpulan bahwa Penerapan PSAK No. 102 tentang akuntansi murabahah pada Bank BNI Syariah Kantor Cabang Mandonga Belum sepenuhnya diterapkan. Pada pengakuan aset, pengakuan diskon, pengakuan piutang, pengakuan keuntungan, pengakuan pelunasan piutang, pengakuan potongan angsuran murabahah dan pengakuan uang muka telah sesuai dengan PSAK No. 102. Namun untuk pengakuan denda belum sesuai dengan ketentuan PSAK No. 102 tentang akuntansi murabahah, hal ini terjadi karena Bank BNI Syariah Kantor Cabang Mandonga tidak menerapkan denda terhadap pembiayaan macet. Penerapan akuntansi murabahah pada Bank BNI Syariah Kantor Cabang Mandonga dalam hal pengukuran untuk murabahah pesanan sudah sesuai namun untuk murabahah tanpa pesanan tidak diterapkan karena Bank BNI Syariah Kantor Cabang Mandonga hanya melakukan pembiayaan jika ada pesanan. Penerapan akuntansi murabahah pada Bank BNI Syariah Kantor Cabang Mandonga dalam hal penyajian dan pengungkapan telah sesuai dengan PSAK No. 102

\section{Implikasi}

Untuk mengetahui penerapan PSAK 102 transaksi pembiayaan murabahah pada Bank BNI Syariah Kantor Cabang Mandonga.

\section{Keterbatasan}

Keterbatasan dalam penelitian ini tertuju pada kurangnya akses pengumpulan data yang mendukung transaksi pembiayaan murabahah pada Bank BNI Syariah Kantor Cabang Mandonga dikarenakan merupakan privasi Bank.

\section{Rekomendasi}

1. Bank BNI Syariah Kantor Cabang Mandonga diharapkan kedepannya dapat terus mengembangkan produk pembiayaan murabahah kepada masyarakat dan dapat menerapkan praktik denda sebagaimana yang diatur dalam PSAK No. 102 walaupun menurut pihak bank denda bersifat memberatkan pihak lain namun dengan menerapkan 
Jurnal Akuntansi dan Keuangan (JAK)

Volume 6, No. 1 Februari Tahun 2021

Page: $67-77$

http://ojs.uho.ac.id/index.php/iak-uho/issue/archive

e-ISSN: 2088-4656

denda dapat menekan tingkat pembiayaan bermasalah menjadi rendah dan membuat nasabah lebih disiplin dalam hal kewajiban mereka yang harus diselesaikan kemudian dana yang diterima dari denda juga bisa disalurkan sebagai dana kebajikan Bank BNI Syariah Kantor Cabang Mandonga juga kedepannya diharapkan mampu memberikan pembiayaan murabahah tanpa pesanan kepada nasabah sebagaimana yang diatur dalam PSAK No. 102.

2. Diharapkan peneliti selanjutnya yang akan mengambil topik yang sama dapat melakukan penelitian dengan menggunakan akad pembiayaan lain seperti Mudharabah, Ijarah, Isthisna, Musyarakah, Salam. Serta memperluas ruang lingkup penelitinnya di lembaga-lembaga keuangan syariah lainnya.

\section{DAFTAR PUSTAKA}

Antonio, Muhammad Syafi'i. 2010. Bank Syariah Dari Teori ke Praktek. Jakarta: Gema Insani Press.

Harahap, Sofyan, Wiroso dan Muhammad Yusuf. 2005. Akuntansi Perbankan Syari'ah. Jakarta: LPFE Usakti. Cet ke 1.

Hariyanto. 2015. Perlakuan akuntansi syariah PSAK No 102 pada BMT UMMAH Banjarmasin. Jurnal Ilmiah Ilmu-Ilmu Keislaman. Vol. 14, No. 2, 185-193.

Ikatan Akuntansi Indonesia. 2019. Pernyataan Standar Akuntansi Keuangan No. 102 Akuntansi Murabahah. Jakarta: Dewan Standar Akuntansi Syariah Ikatan Akuntansi Indonesia.

Jufri dan Sony Warsono. 2011. Akuntansi Transaksi Syariah. Yogyakarta: Buku Akuntansi.

Mardani. 2015. Aspek Hukum Lembaga Keuangan Syariah di Indonesia. Jakarta: PT Kharisma Putra Utama.

Muhammad. 2005. Pengantar Akuntansi Syariah, Edisi Kedua. Jakarta: Salemba Empat.

Muhammad dan Dwi Suwiknyo. 2009. Akuntansi Perbankan Syariah, Yogyakarta: Trustmedia.

Nurhayati, Sri dan Wasilah. 2015. Akuntansi syariah di Indonesia. Jakarta: Salemba Empat.

Pratiwi, Inggrid Eka dan Dina Fitrisia Septiarini. 2014. Analisis Penerapan PSAK - 102 Murabahah (Studi Pada KSU BMT Rahmat Syariah Kediri). Akrual. Vol 1, No. 1, 17-29.

Rusby, Zulkifli. 2015. Lembaga Keuangan Syariah. Pekanbaru: Pusat Kajian Pendidikan Islam FAI UIR.

Rusydi, Muhammad dan Sri Salasiah Nasir. 2009. Perlakuan Akuntansi Murabahah ditinjau dari PSAK No. 102 pada Bank Syariah Mandiri Cabang Makassar. Balance: Jurnal Ilmu Ekonomi Studi Pembangunan. Vol 1, No. 1, 17-29.

Yahdiyani, Nur Safarah. 2015. Analisis Penerapan PSAK No. 59 dan PSAK No. 106 atas Pembiayaan Musyarakah pada PT. BPRS Formes Sleman. Jurnal Profita : Kajian Ilmu Akuntansi 4.5. 